Információközvetítés és közösségépítés - multifunkciós könyvtári hálózatok. Szerk. Kiszl Péter, Németh Katalin. Budapest, ELTE BTK

Könyvtár- és Információtudományi Intézet. 2020. 65-77.

\title{
REKVIEM A BIBLIOGRÁFIÁÉRT? \\ ESETTANULMÁNY EGY SZAKBIBLIOGRÁFIA METAMORFÓZISÁRÓL
}

\section{DIPPOLD PÉTER}

\section{TARTALMI ÖSSZEFOGLALÓ}

Dolgozatomban vázlatosan jellemzem a hagyományos papír alapú bibliográfiák készítésének legfontosabb állomásait, érintem a két dimenzióba rögzített tudásanyag évszázadok alatt kialakult rendszerezési és visszakeresési formáit. Egy konkrét kiadvány, Közép- és DélkeletEurópa kisebbségeinek bibliográfiai kézikönyve alapján elemzem az adatbázisra épülö, de hagyományos módon készült kötet készítésének munkafolyamatait. Erre a tartalmi bázisra épült a Müncheni Südost-Institut európai uniós projektje, amelynek eredményeként létrejött az Ethnodoc webes adatbázis, ami egészen más lehetőségeket teremtett a bibliográfiai információk visszakeresésében és hasznosításában, csakúgy, mint az Erdélyi Magyar Adatbank. Végül néhány német kelet-európai kutatási adatbázis és digitális könyvtár rövid ismertetésével mutatom be a bibliográfiai információk szerepét a jelenlegi rendszerekben.

Ha manapság egy társadalomtudománnyal foglalkozó kutató a friss szakirodalmat szeretné áttekinteni érdeklődési területén, valószínűleg az elektronikus forrásokat használja elöször (nyilván vannak kivételek). Egyre több szakterületen jelennek meg az elektronikus adatbázisok, ugyanakkor egyre kevesebb papíralapú bibliográfia jelenik meg a piacon. Ha felületesen nézzük, úgy tünhet, hogy lassan végére érünk a bibliográfiák korszakának. Ha azonban alaposabban megvizsgáljuk a mai (természetesen most is átmeneti) helyzetet, jóval árnyaltabb képet kapunk a bibliográfiák átalakulásáról. Mert ez a műfaj nem tünik el, hanem (mint annyi minden más napjainkban) csak átalakul.

Dolgozatomban vázlatosan jellemzem a hagyományos papíralapú bibliográfiák készítésének legfontosabb állomásait, érintem a két dimenzióba rögzített tudásanyag évszázadok alatt kialakult rendszerezési és visszakeresési formáit. Ezeket a lehetőségeket kibővítve ma az adatbázisok több szempontú, gyorsabb és egyszerűbb keresést tesznek lehetővé, amelynek elterjedésével a hagyományos módszereket újabb lehetőségek váltják fel.

A bibliográfák készítésének célja a dokumentumok átfogó értelemben vett számbavétele: azaz létezésük megállapítása, a művek azonosítása, jegyzékeik összeállitása és megtalálhatósági helyük rögzítése. ${ }^{1}$ Típusa szerint a bibliográfia lehet általános, szak-, 


\section{DiPPOLD PÉTER}

kurrens és retrospektív, személyhez, földrajzi egységhez és/vagy korhoz kötött, vagy dokumentumtípuson alapuló (pl. sajtóbibliográfia). A bibliográfiai regisztráció nem végcél, hanem egy köztes, de nagyon fontos állomás a dokumentumok szolgáltatásához, mert a leíró formai és tartalmi adatok teszik lehetővé a dokumentumok elérését.

$\mathrm{Az}$ internet elterjedése és az adatbázisok fejlődése természetes módon arra tart, hogy az egyes helyi vagy regionális katalógusok és bibliográfiák összekapcsolásával egyre nagyobb tömegű adat között lehessen keresni. Sőt mi több, az általános internetes keresőrendszerek egyáltalán nem korlátozzák tartalmukat a katalógusokra és bibliográfiákra, a neten található valamennyi elérhető forrásra kiterjednek.

Manapság, az elektronikus virtuális katalógusok korában nem különíthető el egyértelmüen a bibliográfia és a katalógus funkciója: sok, több könyvtár állományát tartalmazó virtuális katalógus mondhatja magáénak a bibliográfiai számbavétel alapvető jellemzőinek teljesítését. A regisztratív típusú adatbázisokban (pl. osztott közös katalógus) a számbavétel és a megtalálhatóság kívánalma sokszor öszszeolvad. Egyre több olyan könyvtári katalógus épül, amelyben csak virtuálisan különül el a könyvtár tényleges állományának leírása és a feldolgozott bibliográfiai rekordok tömege. Hogy csak néhány magyar példát említsek, ilyen az Országos Széchényi Könyvtár (OSZK) katalógusának nemzeti bibliográfiai nézete, az Országos Pedagógiai Könyvtár és Múzeum (OPKM) pedagógiai adatbázisa (PAD), vagy a Fővárosi Szabó Ervin Könyvtár (FSZEK) szociológiai, irodalmi és Budapest bibliográfiája.

$\mathrm{Az}$ újabb keresőrendszerek egyenesen preferálják a több forrásbázison alapuló közös keresést, gondoljunk csak a MOKKA-ODR-NPA, vagy az EPA-HUMANUSMATARKA közös keresőkre. A külföldi és hazai adatbázisfejlesztők a minél szélesebb tartalomban való keresés érdekében ún. discovery rendszereket fejlesztettek, amelyek az intézmény saját forrásanyagán túl akár az előfizetett adatbázisokban is közös felületen teszik lehetővé a dokumentumok megtalálhatóságát. Ilyen rendszer például az EBSCO Discovery Service (EDS), a Proquest Ex Libris Primoja, vagy a Monguz Kft. által fejlesztett Qulto.

\section{A hagyományos bibliográfiák néhány jellegzetessége}

A fiatalok számára talán anakronizmusnak tűnik, de a bibliográfiák számítógép előtti készítésének legfontosabb „alapanyaga” a cédula volt. Méghozzá több száz éven keresztül. A papíron és papírral dolgozás a megoldási lehetőségek széles skáláját hívta életre, és csak most, az elektronikus korban látjuk, milyen korlátokat is hordozott. A végtermék is papíralapú, szerkesztett könyv, annak minden előnyével és korlátaival.

A hagyományos bibliográfiák tartalmának kereshetőségét a bibliográfiák szerkezete és a mutatók rendszere együttesen biztosítja. Az újkori nemzeti bibliográfiák általában elsődlegesen az Egyetemes Tizedes Osztályozás (ETO) (vagy annak valamely változata) alapján szervezik anyagukat, ehhez kapcsolódik a mutatók rendszere. 
A kurrens magyar nemzeti bibliográfia webes füzeteiben jelenleg név-, cím-, tárgy-, valamint ISBN- és ISSN-mutatókat alkalmaznak. A periodikumok esetében ez kiegészül a megjelenési helyek mutatójával, a kottáknál a kiadói lemezszámok, a hangfelvételeknél pedig a gyártási számok mutatójával. ${ }^{2}$

A szakbibliográfiák szerkezete általában az adott tudományterület kutatók által kialakított rendszerét tükrözi vissza, ezáltal biztosítva a tematikus visszakereshetőséget. Az egyedi szakbibliográfiák szerkezetének kialakításában nagy szerepet játszik a feldolgozott anyag jellege és mennyisége is, a tematikát a bibliográfia összeállítója határozza meg; ez természetesen feltételezi a bibliográfus speciális ismereteit is a tudományterületre vonatkozóan. A hagyományos humántudományi szakbibliográfák tematikusan elrendezett fő része jelenti tehát általában a keresés első szintjét. A mutatók rendszere ezt a tematikus keresési módot további lehetőségekkel egészíti ki. A mutatók fajtái változatosak a humántudományi területeken. A leggyakoribb a név- és helymutatók alkalmazása, de gyakran megtalálhatóak a tárgy- és intézménymutatók is ezekben a bibliográfiákban.

A bibliográfiákban a keresés a legkülönbözőbb szempontok alapján történhet. Más információ fontos a szakterületük irodalmában jártas tapasztalt kutatók, mint a diákok, a kezdő kutatók, vagy a laikus érdeklődők számára. Olyan megközelítés is elképzelhető, amely csak egy szerzőre vagy egy földrajzi területre korlátozódik, de sok egyéb egyedi szempont is felmerülhet. A bibliográfiai apparátus a papíralapú kiadványok esetében a hordozó jellege miatt csak egydimenziós, többlépcsős keresést tesz lehetővé.

A papírhordozó következö fontos jellegzetessége a rányomtatott szöveg rendezése, szerkesztése, tipografizálása, aminek hagyományai meghatározzák a könyv esztétikai kinézetét, de ugyanakkor használhatóságát is. Az anyag rendezésében fő szempont az áttekinthetőség biztosítása, a jól szerkesztett bibliográfiának törekednie kell a hibák minimalizásására, a megfelelő tipográfiának pedig a használat egyszerüsítésére.

A papíralapú bibliográfiák egy másik jellegzetessége a hellyel való takarékosság, ami rányomja bélyegét a végtermékre is. A nyomtatott bibliográfiák terjedelmének csökkentését szolgálja a különböző rövidítések alkalmazása, amely ugyan helymegtakarítást jelent, de kényelmetlenné teszi a kötetek használatát.

A következőkben a hagyományos, papíralapú bibliográfia átalakulásának folyamatát szeretném bemutatni egy konkrét példán keresztül.

\section{Közép-Kelet-Európa kisebbségeinek bibliográfiai kézikönyve}

Vizsgált példánk egy 1997-ben megjelent bibliográfia, amely Közép-Kelet-Európa nemzeti kisebbségeinek válogatott bibliográfiáját tartalmazza. ${ }^{3}$ Különös, hogy a bibliográfia készítésekor először arra kellett koncentrálni, hogyan lehet egy bibliográfiai adatbázisból hagyományos, papíralapú kiadványt létrehozni. Ugyanis az adatrögzítés az abban az időben ingyenes Micro-ISIS adatbázisban történt. 


\section{DiPPOLD PÉTER}

Utólag visszatekintve hasonló szituáció volt ez, mint az ősnyomtatványok esetében, amikor megpróbálták a kéziratok formai jegyeit utánozni. Akkor a kéziratosságot váltotta fel a könyvnyomtatás, a kisebbségi bibliográfia készültének idején az analóg adathordozót a digitális. Az elektronikus adatbázis fejlesztése ebben az esetben még nem cél volt, hanem csak eszköz egy nyomtatott kiadvány előállításához.

A bibliográfia 12.000 tételt tartalmaz, földrajzilag 19 országot és régiót foglal magában. Ezek a következők: Közép- és Délkelet-Európa általában, a Habsburg Birodalom, Ausztria, (Cseh)szlovákia, Kárpátalja, Magyarország, Románia, Olaszország, (a volt) Jugoszlávia, Szlovénia, Horvátország, Szerbia, Vajdaság, Koszovó, Bosznia, Macedónia, Albánia, Bulgária és Görögország. A területen élő 35-féle népcsoportra vonatkozó szakirodalom található meg a gyüjteményben, amely főképpen a huszadik századra, és ezen belül az 1918 utáni időszakra koncentrál. ${ }^{4}$

Amiben a bibliográfia tartalmán kívül különbözik a hasonló kiadványoktól, az, hogy az egyes kisebbségekkel foglalkozó fejezetek elé a csoportok történetére, nyelvére, kultúrájára és jelenlegi helyzetére vonatkozó lexikoncikk került. A cikkek a következő információkat tartalmazzák: a csoport neve, névvariánsok, nyelv, vallás, etnikai eredet, a betelepedés ideje, statisztikai táblázatok 1918-tól, és a csoport legfontosabb művelődési-politikai szervezeteinek neve. Önálló publikációként is megállja a helyét az a nagyméretü színes térkép, amely a kötet mellékleteként a közép- és délkelet-európai régió etnikai viszonyait ábrázolja.

De lássuk a kiadvány alapját képező adatbázis jellemzőit. „A Micro-ISIS sikerét az árán túl jó minőségének,... korrekt megoldásainak és annak is köszönhette, hogy megjelenésének idején nem volt más hasonló kategóriájú program az országban.” írta 1992-es cikkében Hunyadiné Naszádos Edit és Tolnai György. ${ }^{5}$ A bibliográfia alapját képező adatbázist Horváth Ádám fejlesztette az OSZK Hungarika osztálya részére, alkalmas volt többféle dokumentumtípus leírására és a hazai könyvtári szabványoknak megfelelő megjelenítésére; az egyes tételek bibliográfiai füzetekbe szervezésére, permutált és ETO-indexek készítésére.

Minden produktum - így valamennyi bibliográfia - megteremtésének alapja a tervezés. Ebbe a folyamatba tartozik a gyüjtőkör tartalmi és formai szempontjainak meghatározása, a földrajzi és időhatárok kijelölése, a válogatási szempontok megnevezése. A tervezés egy következő szintje a konkrét bibliográfia vonatkozásában az adatbázis és a nyomtatott végtermék struktúrájának kialakítása, illetve az indexek megtervezése. 


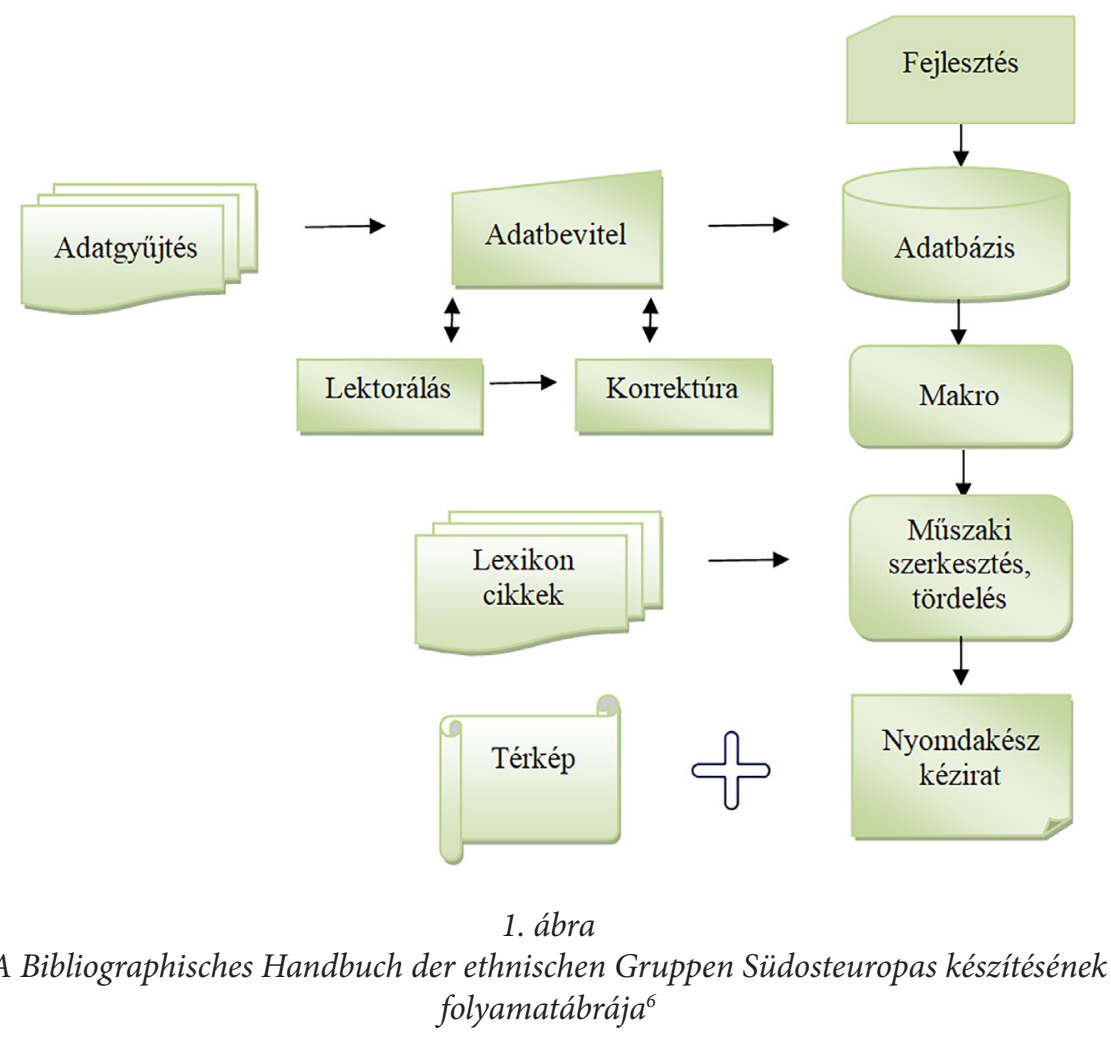

Az 1. ábra egy hagyományos bibliográfia készítésének lépéseit mutatja. Az adatbevitel csak abban különbözött a hagyományos módszerektől, hogy nem cédulán, hanem elektronikusan kerültek rögzítésre az adatok. Ezzel egyszerübbé vált a lektorálás és a korrektúra, valamint az előzetes rendezés is. Önmagában az adatbevitel folyamatában azonban nem történt meghatározó változás a korábbiakhoz képest.

Mint ahogyan a régi séma alkalmazását látjuk viszont a következő lépésekben is: a makró az adatbázis tipografizált outputját hozta létre (betütípusok váltakozása, címfokozatok beállítása stb.), amit a műszaki szerkesztés és a tördelés követett, amíg elöállott a nyomdakész kézirat.

Az adatbázisban történt rögzítés előnyeit a bibliográfia szerkezetének automatikus elöállításakor lehetett igazán érzékelni: az egyes rekordok elöre meghatározott egyedi kódokat kaptak, amelyek alapján a program fejezetekbe rendezte a tételeket. A mutatók összeállítása szintén sokkal egyszerübbé vált az adatbázis segítségével (alfabetikus név- és címmutató, valamint helynévmutató csatlakozik a kiadványhoz).

Összefoglalóan azt mondhatjuk, hogy az elektronikus környezetet a hagyományos kisebbségi bibliográfia elóállításához használták az összeállítók, annak igen hasznos segédeszközeként. 


\section{DiPPOLD PÉTER}

\section{Webes kisebbségi szakadatbázis, az Ethnodoc ${ }^{7}$}

2001-2007 között működött a bajor kormány által finanszírozott Forschungsverbund Ost- und Südosteuropa (forOst) elnevezésü program, ${ }^{8}$ amelynek célja a közép-keleteurópai államok integrálódásának vizsgálata volt. A programban több bajor kutatóintézet és egyetem vett részt, és része lett a kisebbségi problematikával foglalkozó webes adatbank, az Ehtnodoc kiépítése is.

A müncheni Südost-Institut könyvtárának akkori vezetője, Gerhard Seewann által indított projekt Közép- és Délkelet-Európa 21 országának 166 etnikai, nyelvi és vallási kisebbségére vonatkozó adatok és dokumentumok virtuális gyüjteménye. A kisebbségi bibliográfia mellett több egyéb információforrást is tartalmaz a portál. Ezek a következők:

- az egyes csoportok történetére, jelenlegi helyzetére, nyelvére, kultúrájára stb. vonatkozó tömör, de informatív leírások, lexikoncikkek,

- forrásdokumentumok, amelyek az egyes kisebbségi csoportokra vonatkozó jogszabályi, történeti és politikai forrásokat teszik teljes szövegként visszakereshetővé,

- a kisebbségekre vonatkozó népszámlálási statisztikák 1900-tól napjainkig,

- térképi feldolgozások, különös tekintettel a kisebbségi területekre és a migrációs folyamatokra,

- a kisebbségek mindannapjait, kultúráját és társadalmát ábrázoló képek gyüjteménye,

- kisebbségi intézmények, valamint kisebbségkutatással foglalkozó intézmények honlapjainak linkgyüjteménye.

Az Ethnodoc program esetében is látható, hogy a bibliográfiai adatokat teljes szövegü dokumentumok és faktografikus adatok egészítik ki a teljesebb körü áttekintés érdekében.

Kifejezetten az adatbank számára készült a Nightfire-Bibliomaster programrendszer, amelynek fejlesztője Dippold András volt. Jellemzői:

- relációs adatbázis az adatok tárolására,

- XML az adatok betöltésére és exportálására,

- távoli adatbáziskapcsolat,

- Unicode a többféle karakter kezelésére.

A következő indexek váltak közvetlenül kereshetővé:

- címek listája,

- személynevek listája,

- testületek listája,

- helységek listája,

- találkozók listája,

- sorozatok listája. 
Az adatbázis a bibliográfai kézikönyv számára fejlesztett kódrendszert használta fel az alapvető keresési lehetőségekhez. Ez azt is eredményezte, hogy szemben több más webes adatbázissal, itt lehetőség nyílott a tematikus keresésre is (2. ábra). A megjelenítés az adatbázis-navigátor nevủ menüpontból indítható, és lehetővé teszi a területi vagy etnikumok szerinti szerkezet bemutatását.

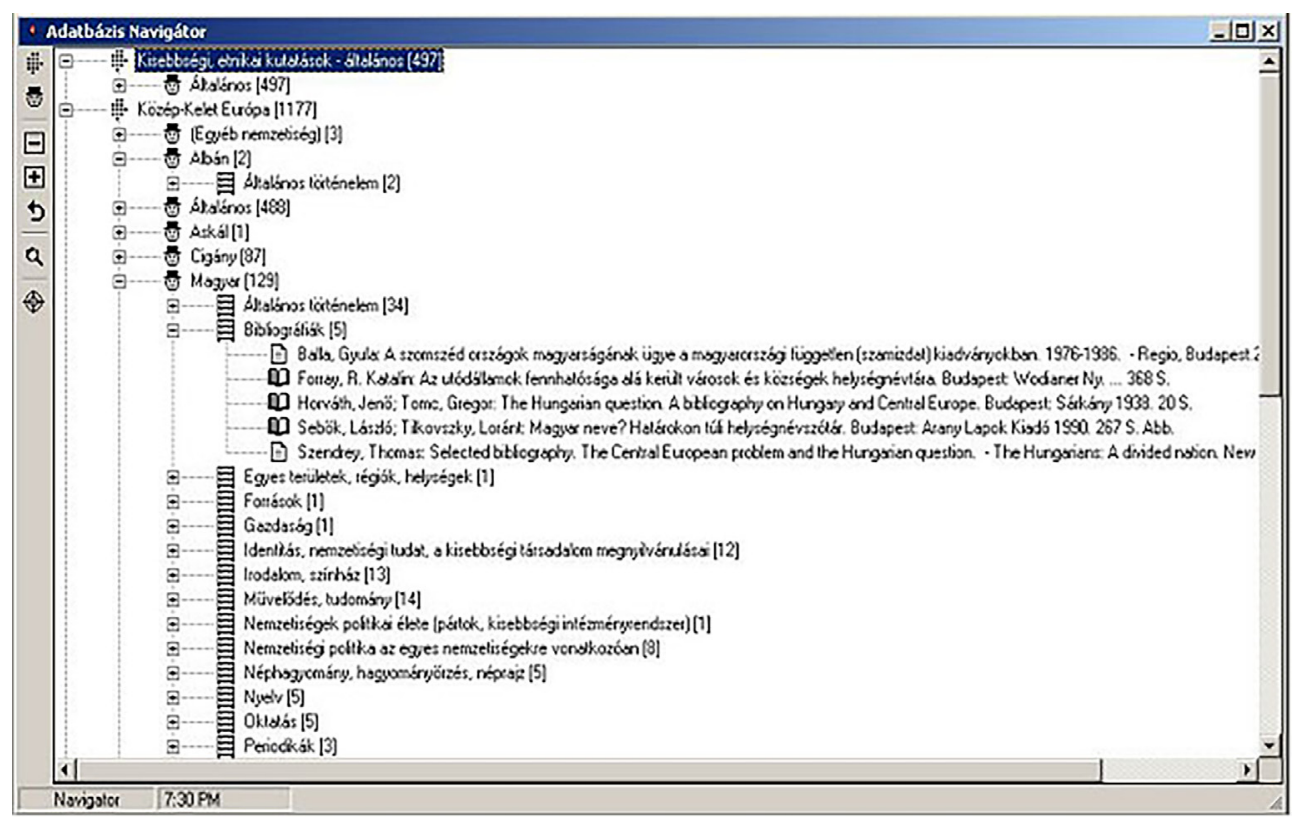

\section{2. ábra}

Az Ethnodoc adatbázis-navigátora a tematikus keresés biztositására9

A papíralapú kiadványhoz képest az adatbázis a következő minőségi változásokat biztosította:

- a bibliográfiai leíró rekordok könyv helyett strukturált adatbázisba kerültek;

- a könyvben a fejezetek, rekordok sorrendje fix - az adatbázis nagyon sokféle rendezési, válogatási lehetőséget ad -, másodpercek alatt kereshető a teljes adathalmaz különböző szempontok szerint;

- az adatok a weben azonnal elérhetővé válnak.

Ehhez jön még hozzá, hogy a bibliográfiai adatok mellett közös felületen válnak megtalálhatóvá a fentebb említett lexikoncikkek, statisztikák, térképek, forrásdokumentumok és linkek, tehát a bibliográfiai funkció kiegészült egyéb szolgáltatásokkal. 


\section{DiPPOLD PÉTER}

\section{Erdélyi Magyar Adatbank ${ }^{10}$}

A kolozsvári Transindex internetes portál és a Jakabffy Elemér Alapítvány a romániai magyarságra vonatkozó adatok széles körü digitalizálását és közzétételét tűzte ki célul. A Transindex Erdélyi Magyar Adatbankjában a bibliográfiák mellett statisztikák, kisebbségekre vonatkozó kronológiák, helységnévtárak, kataszterek szerepelnek közös keresőfelület alá rendezve. A kisebbségkutatás forrásai és segédletei mellett a portál természettudományi adatbázisokat, élő elektronikus folyóiratokhoz kapcsolódó linkeket és elektronikus szótárakat is tartalmaz. Az adatbank - szemben előző példánkkal - nem a könyvtárak, hanem a kutatók kezdeményezésére jött létre, és ma is folyamatosan gyarapodik. Keresési szempontból kettős lehetőséget kínál fel a portál: bármilyen kulcsszóra kereséssel a nyitólapról indulhatunk, egyébként minden egyes müfajban (bibliográfiában, statisztikában, kronológiában) külön-külön is kereshetünk az adott dokumentum lehetőségeinek megfelelően. Ez általában azt jelenti, hogy az egyes szerzők által a papíralapú bibliográfia számára kialakított szerkezet az elektronikus formában is visszaköszön. Érdekes elegyét találjuk meg tehát ebben a szerkesztési filozófiában a hagyományos és az újszerü szemléletnek. A Transindex - talán éppen kutatói indíttatása miatt - általában megtartja a bibliográfusok által kialakított hagyományos szerkezetet, kiegészítve azt az elektronikus visszakeresés további lehetőségeivel (keresés megjelenési időre, helyre, mutatókra stb.).

Az adatbank része egy bibliográfiai gyüjtemény, amely a határon túl élő magyarság két világháború közötti történetének forrásait tartalmazza. ${ }^{11} \mathrm{~A}$ több mint 6000 bibliográfiai rekordot tartalmazó adatbázisban a kulcsszavas keresés mellett a közlemények tárgyéve, a szerző, az ország, a tárgyszó és a helységnév alapján lehet szűkíteni a keresést. A bibliográfiai rekordokban szereplő tárgyszavak élő linkként funkcionálnak, amely alapján hólabda módszerrel lehet tovább navigálni (3. ábra). 


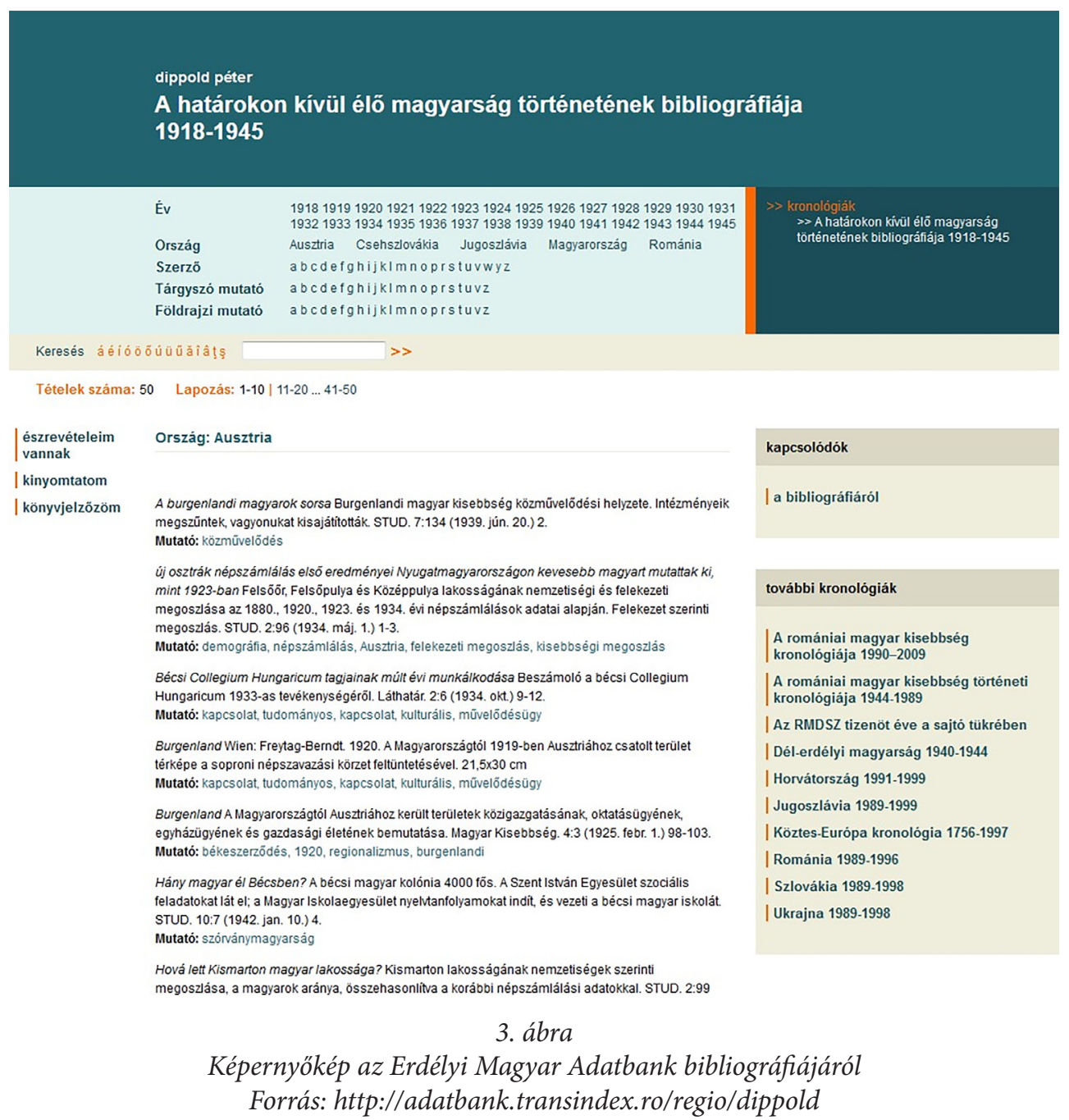

A kisebbségtudomány területén megfigyelhetö, hogy a '90-es években és a 2000-es évek első évtizedében még főként az adatbázisok gyűjtőköre határozza meg a tartalmat, az adatgyüjtés tehát továbbra is meghatározott tematika szerint történt. Bár már ekkor is megjelentek a különböző intézmények (könyvtárak, kutatóintézetek stb.) közötti együttműködési rendszerek csírái, az adatbázisok sokszor projektek keretei között készültek. A gyüjtőkörön kívüli bibliográfiai és egyéb adatok eleve nem kerültek a rendszerbe, tehát elsődlegesnek tekinthető a tartalmi (itt kisebbségi vonatkozású) elözetes szelekció. Egy másik jellegzetessége ennek a korszaknak, hogy még kevésbé jelentek meg a fulltext dokumentumokra mutató linkek, mert ekkor a digitalizáció korai szakaszát élte, és nem állt rendelkezésre elegendő mennyiségủ digitális forrás. 


\section{DipPOLD PÉTER}

\section{Kelet-Európa-kutatás Németországban - a mai helyzet}

Az előző fejezetben a nyomtatott kisebbségi bibliográfián alapuló két szakadatbázis vázlatos ismertetését olvashattuk.

A Transindex adatbankja itt meg is állt, informatikai fejlesztések helyett inkább a tartalmi kibővítés jöhet számításba. Az Ethnodoc mint projekt befejeződött, de remélhetően a feldolgozott adatok a német kutatóintézeti és egyetemi hálózatokban tovább élnek.

Az alábbiakban néhány német kutatóintézet, egyetem és kiadó Kelet-Európával foglalkozó adatbázisát ismertetem.

\section{OSMIKON - Kelet-, Kelet-Közép- és Dél-Európa kutatási portálja ${ }^{12}$}

A Bajor Állami Könyvtár programja, amelyet 1949-től támogat a Német Kutatási Alapítvány. A könyvtár a régió kutatásának német referenciagyüjteménye, a portál nemzetközileg elismert állományán, valamint több egyetemi szférán kívül működő német Kelet-Európa kutatóintézet könyvtárának gyüjteményein és adatbázisain alapul. ${ }^{13}$ Ezen kívül a portál hozzáférést biztosít a Németországban nem elérhető szakirodalomhoz is a nemzetközi adatbázisok osmikonSEARCH-be történő integrálásával. Az OSMIKON keresőfelülete discovery rendszerként funkcionál.

Célterületei: Albánia, Bosznia-Hercegovina, Bulgária, Észtország, Koszovó, Horvátország, Lettország, Litvánia, Moldova, Montenegró, Modern Görögország, Észak-Macedónia, Lengyelország, Románia, Oroszország, Szerbia, Szlovákia, Szlovénia, Csehország, Ukrajna, Fehéroroszország, Ciprus.

Herder-Institut: Könyvtári és bibliográfiai portál ${ }^{14}$

A marburgi Herder Institut Közép- és Kelet-Európa történetével foglalkozó kutatóintézet. Kutatási területe Lengyelország, Észtország, Lettország, Litvánia, Csehország és Szlovákia történetét foglalja magában.

Mintegy 500 ezer kötetes könyvtárral rendelkezik, valamint jelentős számú fotó- és térképgyüjteménnyel. Speciális szolgáltatásként tartják fenn könyvtári és bibliográfiai portáljukat, amelyben a Közép- és Kelet-Európával foglalkozó publikációkat közös felületen teszik kereshetővé. Az adatbázisban monográfiák, gyüjteményes kötetek közleményei, folyóiratcikkek, forráskiadások, referenciaművek, bibliográfiák, ismertetések és konferenciajelentések szerepelnek.

\section{OstDok - Osteuropa-Dokumente Online ${ }^{15}$}

Kizárólag elektronikus formában (digitalizált vagy digitálisan született) dokumentumokat tartalmaz a Kelet-Európa-kutatás interdiszciplináris témakörében. Valamenynyi tétel szabadon elérhető az interneten. A dokumentumokat vagy online módon eredeti helyükön tudja a használó megtekinteni, vagy javaslatot kap azokra a távoli gyüjteményekre, ahol a keresett elektronikus dokumentum megtalálható. 
Az OstDok a Bajor Állami Könyvtár, a Collegium Carolinum, a Herder és a Leibniz Intézetek együttműködésében készül. A korábban ismertetett OSMIKON portálon keresztül kereshető, mintegy 48 ezer teljes szövegü dokumentumot tartalmaz.

Közép- és Kelet-Európa online könyvtára - Central and Eastern European Online Library ${ }^{16}$

Kereskedelmi vállalkozás, amely a Kelet-Európában megjelent és a régióról szóló e-folyóiratokat és e-könyveket tartalmazza, főképpen a társadalomtudományok területén. Jelenleg mintegy 2000 folyóiratot, 480.000 cikket, több, mint 2200 e-könyvet és 2500 szürke irodalmi dokumentumot foglal magában az adatbázis. A vállalkozás 2010-ben indult, könyvtárak és egyéb intézmények előfizethetnek a szolgáltatásra.

A Kelet-Közép-Európa-kutatás területén a német egyetemi és kutatási adatbázisok alapján a következő általános trendek figyelhetők meg:

- kutatóintézeti, egyetemi és állami könyvtárak kezelésében épülnek adatbázisok;

- széles dokumentumbázis jellemző rájuk;

- bibliográfiai és katalógusinformációk egyaránt megtalálhatók bennük;

- a fulltext dokumentumok aránya jelentősen megnőtt;

- megjelentek kereskedelmi résztvevők is a piacon.

Ha a jelenlegi helyzetet összevetjük a szakadatbázisok korábbi korszakával, megfigyelhető az a trend, hogy a hagyományos bibliográfiákra is jellemző tematizált, célzott gyűjtést az egyre szélesebb forrásbázis biztosítása váltja fel. Minél nagyobb számú dokumentum található meg az adatbázisokban, annál nagyobb a valószínűsége, hogy a kutató különböző szürésekkel megtalálja a releváns információt, illetve ma már magát a dokumentumot is. A digitalizálás hétköznapivá válásával a bibliográfiai információ egyre inkább a teljes dokumentumhoz vezető utat jelenti.

\section{Összegzés}

A használók, kutatók számára nem a bibliográfiai adat, hanem magának a dokumentumnak a megtalálása a cél. Korábban a dokumentumhoz több lépcsőn keresztül juthattak csak el: a bibliográfiából azonosíthatták a dokumentum alapadatait és jó esetben megtalálhatósági helyét. Ezután fel kellett keresni azt a gyüjteményt, ahol a dokumentum elérhető, és csak ezután juthattak a forráshoz. Manapság ez az út lerövidülhet akár egy lépcsőre is, ha a keresett forrás elektronikus formában is szabadon hozzáférhetö. Az elektronikus környezet arra is lehetőséget nyújt, hogy a bibliográfiai rekordokhoz teljes dokumentumokat és/vagy tematikusan kapcsolódó egyéb adatokat is rendeljünk.

A kisebbségkutatási bibliográfia példáján keresztül azt az átalakulási folyamatot próbáltam bemutatni, ami a hagyományos bibliográfiától a projektalapú szakadatbázisokon keresztül napjaink adatbázisaihoz és digitális könyvtáraihoz vezet. 


\section{DiPPOLD PÉTER}

Mint minden változás, ez az átalakulás is áldozatokkal jár. A tudós bibliográfusok által míves módon, évek hosszú munkájával összeállított vaskos kötetek jelentősége csökken, és ezzel háttérbe szorul az a személyesség, ami az ilyen típusú bibliográfiák jellemzője: a bibliográfusok egyéniségének tükröződése a műben. A kötetek forgatása helyett a kutató az interneten elérhető adatbázisokat és az egyes gyűjtemények katalógusait használja, vagy egyszerüen beírja az ismert adatokat egy internetes keresőbe. A keresés gyorsabb, és eredményessége valószínübb ezen a módon: nyilvánvalóan ez a fó cél, s a jövő útja. Közben azonban elveszhet az adatvadászat személyessége és háttérbe szorul egy - a kutatáshoz mindig szorosan kapcsolódó - tradicionális hivatás: a tudós bibliográfusé.

\section{Irodalom és jegyzetek}

1. HAGLER, Ronald: The bibliographic record and information technology. 3. ed. ChicagoLondon, ALA-CLA, 1997. 13. p.

2. Magyar nemzeti bibliográfia. Könyvek bibliográfiája. Forrás: http://www.oszk.hu/ mnbwww/K/BIBLI.HTML [2019. július 1.]

3. Bibliographisches Handbuch der ethnischen Gruppen Südosteuropas. Hrsg. von Gerhard Seewann und Péter Dippold. Bd. 1-2. München, Oldenbourg, 1997. (SüdosteuropaBibliographie. Ergänzungsband; 3.) XC, 638 p., XLVII, 639-1450. p.

4. DIPPOLD Péter: Délkelet- és Közép-Európa kisebbségeinek bibliográfiai kézikönyve. = Könyvtári Figyelö, 45. évf. 1. sz. 1999. 31-39. p.

5. HUNYADINÉ NASZÁDOS Edit - TOLNAI György: Könyvtári rendszerek PC környezetben. = Könyvtári Figyelö, 38. évf. 4. sz. 1992. 621. p.

6. DIPPOLD Péter: Délkelet- és Közép-Európa kisebbségeinek bibliográfiai kézikönyve. = Könyvtári figyelö, 45.évf. 1.sz. 1999.35.p. Forrás: http://epa.oszk.hu/00100/00143/00029/ pdf/EPA00143_konyvtari_figyelo_1999_1_031-039.pdf [2019.június 20.]

7. Ethnodoc. Forrás: www.ethnodoc.eu [2019. július 3.] Az Internet archívum wayback machine alapján ezen a webcímen 2011-2018 között működött az adatbank, 2019-től a szolgáltatás megszünt.

8. Forschungsverbund Ost- und Südosteuropa. Forrás: http://www.forost.de [2019. július 1.]

9. Az Ethnodoc adatbázis-navigátora a tematikus keresés biztosítására. DIPPOLD András: Nightfire Viewer felhasználói dokumentáció 1.0. 8. p. (Kézirat)

10. Adatbank. Erdélyi magyar elektronikus könyvtár. Forrás: http://www.adatbank.ro [2019. július 1.]

11. DIPPOLD Péter: A határokon kívül élő magyarság történetének bibliográfiája 1918-1945. Forrás: http://adatbank.transindex.ro/regio/dippold [2019. július 1.]

12. OSMIKON. Das Forschungsportal zu Ost-, Ostmittel und Südosteuropa. Forrás: https:// www.osmikon.de [2019. július 1.]

13. Kilenc különböző könyvtár katalógusa, 8 sajtó- és cikkadatbázist, 5 digitális könyvtárat, 6 szakbibliográfiai gyüjteményt és 2 internetes linkgyüjteményt tartalmaz a portál. 
14. Herder-Institut für historische Ostmitteleuropaforschung - Institut der Leibniz-Gemeinschaft. Forrás: https://hds.hebis.de/herder/index.php [2019. július 1.]

15. Ostdok. Osteuropa-Dokumente online. Forrás: https://www.osmikon.de/metaopac/start. do?View=ostdok [2019. július 1.]

16. Central and Eastern European Online Library. Forrás: https://www.ceeol.com [2019. július 1.]

Dippold Péter a Fővárosi Szabó Ervin Könyvtár Központi Könyvtárának igazgatója, mellékállásban 2016-tól az ELTE BTK Könyvtár- és Információtudományi Intézetének adjunktusa. 2000-2005 között a Könyvtári Intézet igazgatója, majd az Országos Széchényi Könyvtár főigazgató-helyettese. Kutatási területe: a közkönyvtárak fejlesztésének lehetséges irányai az internet korában a trendek tükrében, valamint a bibliográfia elméleti kérdései.

ORCID 0000-0001-9000-3392 